\title{
RESIPROSITAS DALAM EKONOMI ISLAM, TELAAH TERHADAP AKAD KERJASAMA ANTARA INDUK SEMANG DENGAN PENGRAJIN DI NAGARI PANDAI SIKEK
}

\author{
Syukri Iska**, Elsy Renie** dan Zikra Rahmi* \\ ** Dosen PPs IAIN Batusangkar email syukriiska@iainbatusangkar.ac.id, \\ elsyrenie@iainbatusangkar.acid \\ * Mahasiswa PPs IAIN Batusangkar email zikrarahmi57@gmail.com
}

\begin{abstract}
This study is the unclear forms of songket weaving business cooperation between the property owner and the craftsmen in Nagari Pandai Sikek, as well as the forms of songket weaving business cooperation in terms of syari'ah economic law. The purpose of this discussion is to find out the forms of songket weaving business cooperation and how to review syari'ah economic law on these forms of songket weaving business collaboration. This type of research is field research The data collection technique uses is through interviews. Data processing is descriptive qualitative manner. The results of this research are In Islamic economics the forms of songket weaving business cooperation in Nagari Pandai Sikek are included in the ujrah contract is included which is "reciprocal". The practice wages in Nagari Pandai Sikek is not only in the form of material relationships but also oriented to social relationships that are tied to trust.
\end{abstract}

Keywords: Resiprositas, ekonomi Islam, Akad Kerjasama

\section{PENDAHULUAN}

Islam merupakan agama yang bersifat universal dan komprehensif. (Suliastani, 2018: p. 127). Universal berarti bahwa Islam diperuntukkan bagi seluruh umat manusia dan dapat diterapkan di berbagai waktu dan tempat sampai akhir zaman. (Suliastani, 2018: p. 127). Agama Islam merupakan ajaran yang mencakup seluruh aspek kehidupan manusia, ajaran ini mencakup berbagai seperti aspek sosial, budaya, politik, hukum dan ekonomi. (Syahril, 2019: p. 339). Sedangkan komprehesif berarti Islam merupakan agama yang terbuka, serta ajarannya bersifat inklusif yang menerima berbagai dinamika dan perkembangan era modernisasi dan globalisasi. (Syahril, 2019: p. 340).

Berkenaan dengan Islam yang bersifat universal khususnya dalam aspek ekonomi Islam, perintah bermuamalah umumnya menggunakan ayat- ayat yang bersifat zhanni (Azwar Iskandar \& Khaerul Aqbar, 2019: p. 94), hal ini bertujuan agar umat Islam memikirkan urusanurusan duniawinya, dan juga agar umat Islam mampu berkreasi dengan 
kegiatan- kegiatan ekonomi yang ada dan tumbuh di masyarakat (Muhammad, 2004: p. 77). Dalam praktek pelaksanaan ekonomi Islam Islam sangat memperhatikan unsur etika dalam pelaksanaannya, serta Islam juga melarang unsur eksploitasi berupa riba, gharar, maysir dan transaksi-transaksi yang belum jelas bentuknya. (Nur, 2015, p. 648).

Salah satu bentuk bentuk kegiatan ekonomi yang ada di tengah masyarakat adalah kerjasama. Kerjasama adalah kegiatan ekonomi yang dilakukan oleh dua orang atau lebih untuk usaha tertentu masingmasing pihak berkontribusi berupa dana dengan kesepakatan bahwa keuntungan dan resiko ditanggung bersama sesuai dengan kesepakatan. (Nawawi, 2012; p. 151). Dan salah satu bentuk pelaksanaan kerjasama bisnis yang ada di masyarakat adalah kerjasama bisnis tenun songket antara induk semang dengan pengrajin yang ada di Nagari Pandai Sikek. Menurut data BPS Tanah Datar tahun 2018 sektor bisnis tenun Pandai Sikek sebanyak 147 buah (BPS Tanah Datar, 2018, p. 58).

Kerjasama bisnis tenun songket di Nagari Pandai Sikek menerapkan bisnis kerja sama antara pengrajin dengan induk semang. Kerjasama bisnis ini dalam bentuk induk semang memberikan manfaat dari suri dan benang-benang kepada masing- masing pengrajinnya untuk pembuatan selandang ataupun kodek dan pengrajin mengerjakan tenunan sesuai dengan permintaan dari induk semang dan permintaan dari seorang pelanggan/ pembeli. Praktek kerjasama bisnis tenun, merupakan praktek kerjasama antara induk semang dengan pengrajin. Di dalam praktek tersebut, persekutan ini dalam bentuk induk semang dan pengrajin, mereka bersama- sama berkonstribusi untuk menghasilkan sebuah tenunan. Selain sebagai pemberdaya ekonomi masyarakat, dengan memberikan manfaaat dari suri-nya, Induk semang juga berfungsi layaknya sebagai "lembaga keuangan" bagi para pengrajinnya dengan memberikan hadiah, tunjuangan, utang, bahkan memberikan zakat bagi para pekerjanya.

Dalam ekonomi Islam, praktek kerjasama bisnis dikenal dengan nama syirkah. Di dalam syirkah ini, terkandung dua komponen yaitu adanya persekutuan antara dua pihak, baik di dalam bentuk modal, pengerjaan maupun di dalam keuntungan. (Muslich, 2010, p. 341). Syirkah merupakan akad atau perjanjian antara dua belah pihak untuk bekerja sama di dalam kegiatan usaha, dimana modal dan keuntungan dimiliki oleh bersama dan dibagi bersama kepada pihak yang 
berserikat. Terdapat penelitian terdahulu yang juga membahas tentang aspek kerjasama bisnis, diantaranya sebagai berikut:

Zainuddin \& Riri Purnama Sari ( 2019) ia berpendapat bahwa Keuntungan dalam akad mudharabah dibagi menurut kesepakatan kedua belah pihak yang tercantum dalam kontrak yang disepakati, sedangkan di dalam kerugian ditanggung oleh pemberi modal, dan apabila kecacatan disebabkan karena kelalaian dari pengelola, maka pengelola wajib bertanggung jawab. Hal ini juga didukung oleh Evita Edila Putri, Zaini Abdul Malik Dkk, (2017-2018), ia mengatakan bahwa di dalam akad syirkah keuntungan dibagi sesuai dengan kesepakatan antara para mitra, dan kerugian akan dibagikan menurut proposi modal. Melalui akad syirkah, masing masing pihak yang bersekutu akan saling memberikan modal untuk menjalankan usaha. Kemudian pembagian keuntungan yang diperoleh dari hasil uasaha didasarkan atas nisbah (\%). (Turmudi, 2017:P. 35).

Secara eksplisit tujuan penelitian ini adalah untuk menelaah bentukbentuk kerjasama bisnis bentukbentuk kerjasama bisnis tenun songket di Pandai Sikek dan tinjauan hukum ekonomi syari'ah terhadap bentuk- bentuk kerjasama bisnis tenun songket Pandai Sikek.
Bagian kedua dari tulisan ini mengulas tentang metodologi dan data yan digunakan, bagian ketiga membahas tentang hasil penelitian dan pembahasan, sedangkan bagian kesimpulan disajikan pada bagian keempat dan menjadi bagian penutup.

\section{METODE PENELITIAN}

Adapun jenis penelitian yang penulis gunakan di dalam penelitian ini adalah penelitian kualitatif menggunakan pendekatan studi kasus (Creswell, 2009; p. 30). Penelitian ini berkonsentrasi pada eksplorasi bentuk- bentuk kerjasama bisnis tenun songket dari sisi hukum ekonomi syari'ah. Penelitian ini dilakukan selama rentang waktu tiga bulan yakni bulan Juni- Agustus 2020, dengan lokasi penelitian di Nagari Pandai Sikek, Kecamatan Sepuluh Koto, Kabupaten Tanah Datar, dengan alasan bahwa Nagari Pandai Sikek merupakan sentral bisnis usaha tenun di Kabupaten Tanah Datar

Sedangkan sumber data yang penulis gunakan terbagi atas dua macam yakninya sumber data primer dan sumber data sekunder. Sumber data primer pada penelitian ini masyarakat Nagari Pandai Sikek, yang berprofesi sebagai induk semang sebanyak empat orang dan pengrajin tenun songket sebanyak enam orang. Sedangkan data sekunder pada 
penelitian ini adalah seorang bundo kanduang di Nagari Pandai Sikek. Dalam penelitian ini, penulis memilih sampel secara purposive sampling (Sugiyono, 2015, p. 366) yaitu dipilih dengan pertimbangan dan tujuan tertentu. Dari sumber data yakninya 147 orang induk samang yang berada di seluruh Nagari Pandai (BPS Tanah Datar, 2018, p. 58) peneliti memilih sebanyak empat orang induk semang , hal ini untuk mewakili masingmasing jorong yang ada di Nagari Pandai Sikek

Teknik pengumpulan data yang penulis gunakan adalah teknik wawancara mendalam dengan induk semang beserta pengrajin tenun yang tergabung di dalamnya. (Sugiyono, 2015, p. 376). Setelah data dikumpulkan melalui wawancara kemudian dikelompokkan dan memilahnya berdasarkan tujuan masing-masing pertanyaan, kemudian data diklasifikasikan tersebut dianalisis dengan metode deskriptif.

HASIL PENELITIAN PEMBAHASAN

\section{Hasil Penelitian}

\section{a. Deskripsi Wilayah}

Pandai Sikek adalah salah satu Kenagarian yang ada di Kecamatan $X$ Koto, Kabupaten Tanah Datar, Provinsi Sumatera Barat. Nagari Ini berada di bawah kaki gunung
Singgalang, selain itu Nagari ini juga berhadapan dengan gunung Marapi, dan secara sekilas terlihat bahwa Nagari tersebut diapit oleh kedua gunung ini yang menyebabkan topografinya bergelombang dan menciptakan pemandangan yang cukup indah terhadap Nagari tersebut. Ketinggian Pandai Sikek di atas permukaan air laut sekitar 1200 M. hal ini menyebabkan suhu daerah ini sekitar 25- 30 Celcius. (Arsip Nagari Pandai Sikek, tahun 2019).

Jarak Nagari Pandai Sikek dengan ibu kota Provinsi Sumatera Barat, yakninya Kota Padang, sekitar $84 \mathrm{Km}$, dan jarak ini dapat ditempuh dengan kendaraan bermotor \pm 2 jam, sedangkan jarak dengan ibukota Kabupaten Tanah Datar, Kota Batusangkar dengan kendaraan bermotor \pm 1 jam dengan jarak $40 \mathrm{~km}$ (Christyawati, 2011, p. 212).

Pandai Sikek adalah salah satu Nagari yang terletak di Kecamatan Sepuluh Koto, Kabupaten Tanah Datar yang memiliki luas 10,66 KM² DAN yang terdiri dari empat jorong yakninya jorong Baruah dengan luas 1,60 Km², jorong Koto Tinggi dengan luas 3,20 $\mathrm{Km}^{2}$ jorong Pagu- Pagu dengan luas $1,60 \mathrm{Km}^{2}$ dan jorong Tanjung dengan luas 4,27 $\mathrm{Km}^{2}$. (BPS Tanah Datar, 2018, p. 7). Nagari Pandai Sikek berbatas dengan ( Arsip Nagari Pandai Sikek, 2019) 


$\begin{array}{llr}\text { Sebelah Utara } & \begin{array}{l}\text { Nagari } \\ \text { Laweh } \\ \end{array} & \begin{array}{r}\text { Padang } \\ \text { Sungai }\end{array} \\ & \text { Kabupaten Agam } \\ \text { Sebelah } & \text { Nagari Koto Laweh } \\ \text { Selatan } & \text { Kecamatan X Koto } \\ & \text { Kabupaten Tanah } \\ \text { Sebelah } & \text { Datar } \\ \text { Timur } & \text { Nagari Koto Baru } \\ & \text { Kecamatan X koto } \\ & \text { Kabupaten Tanah } \\ & \text { Datar }\end{array}$

Sebelah Barat Gunung Singgalang
Warga Nagari Pandai Sikek berjumlah \pm 55. 223 merupakan masyarakat homogen, yang merupakan warga asli Nagari Pandai Sikek, dan profesi yang digeluti masyarakat Nagari pun beragam yakninya petani sebanyak 437 orang, PNS sebanyak 35 orang, Pengrajin sebanyak 1619 orang, pengusaha kecil, sedang dan menengah sebanyak 93 orang, perangkat desa sebanyak 11 orang, petani sebanyak 1275 orang, peternak sebanyak 398 orang, pensiunan/ purnawiran sebanyak 35 orang, penjahit 13 orang, montir sebanyak 5 orang, sopir 20 orang, karyawan swasta 19 orang, tukang kayu, sebanyak 93 orang, tukang batu sebanyak 24 orang dan guru swasta sebanyak 86 orang (Arsip Nagari Pandai Sikek, tahun 2019).

Di Nagari Pandai Sikek profesi utama yang digeluti masyarakatnya berupa pengrajin tenun, karena Nagari Pandai Sikek merupakan sentra kerajinan tenun dan kerajinan ukiran, sehingga Nagari Pandai Sikek terkenal dengan tenun songketnya disamping dengan ukirannya. Para pengrajin tenun songket Pandai Sikek tersebar disetiap jorongnya.

Para penenun yang ada di Nagari Pandai Sikek umumnya bervariasi dari muda hingga tua, yakni sekitar berumur 10 tahun- 50 tahun. Para gadis- gadis umumnya mereka belajar bertenun ketika mereka masih Sekolah Dasar berumur sekitar 10-12 tahun. Proses belajar menenun yang dipelajari oleh gadis- gadis tersebut memakan waktu yang cukup lama yakninya berbulan- bulan hingga bertahun-tahun, dan mereka umumnya dianggap mahir ketika berumur 17 tahun. (Christyawati, 2011, p. 216). Para gadis- gadis ini umumnya mereka hanya mengerjakan hasil upahan yang cukup mudah yakninya tuhuak ampek (benang empat), hal ini disebabkan karena mereka mengerjakannya sebagai sampingan disela- sela sekolah mereka, dan umumnya mereka mengerjakannya dalam rentang waktu yang cukup lama yakninya satu bulan, dan hal ini umumnya dimengerti oleh induk samang, karena mereka juga menganggapnya sebagai proses belajar bagi para gadis- gadis tersebut. Resiprositas dalam Ekonomi Islam... $\mid 131$ 
Sedangkan bagi para penenun professional adalah penenun yang benar- benar fokus untuk pengerjaan ini, dan menganggapnya sebagai profesi adalah ibu-ibu rumah tangga. Mereka umumnya menenun bukanlah sebagai hobi semata, akan tetapi juga sebagai mata pencarian dari menenun tersebut. (Christyawati, 2011, p. 2017).

Selain itu ada beberapa masyarakat di Nagari Pandai Sikek yang berprofesi sebagai induk semang yang memiliki galeri yang menjual berbagai macam hasil kerajinan tenun songket, dan mereka merupakan induk samang yang memberikan surinya untuk masing- masing pekerja dan mereka mempunyai banyak anggota/ anak semang-nya masingmasing. Dan sebagian dari induk samang mereka tidak memiliki galeri tertentu, akan tetapi ia juga berprofesi sebagai pedagang lain seperti wid, Leni, Darni. Wid, ia merupakan seorang induk samang, akan tetapi ia tidak memiliki galeri tertentu, profesi utama yang dilakukan oleh Wid adalah sebagai pedagang pupuk, dan dalam toko pupuknya, ia memiliki ruangan tertentu tempat ia memajang hasil tenunan songket Pandai Sikek. Leni, ia merupakan seorang induk samang, akan tetapi ia juga tidak memiliki galeri tertentu, ia hanya memajang hasil tenun songket Pandai Sikek di pojok rumahnya, dan Darni, ia merupakan induk samang, dan dia juga tidak memiliki galeri, dan ia kembali menjual hasil tenunan songket Pandai Sikek ke Bukittinggi.

\section{b. Bentuk- Bentuk Kerjasama Bisnis Tenun Songket di Nagari Pandai Sikek}

Di dalam pengerjaan tenun songket Pandai Sikek, terbentuklah kerjasama antara pengrajin dengan pemilik suri yang dikenal dengan induk samang. Menurut Gouzaly Saydam ia berpendapat bahwa makna induk samang dapat difahami dengan dua konsepsi yaitu: pertama hubungan khusus antara dua orang yang saling berpiutang, kedua majikan (Saydam, 2004, p. 333).

Berdasarkan wawancara yang penulis lakukan dengan pengrajin dan induk semang Pandai Sikek adapun bentuk kerjasama yang dilakukan antara induk semang dengan pengrajin tenun songket Pandai Sikek adalah sebagai berikut:

a. Induk semang memberikan suri-nya kepada masing- masing pengrajinnya, dan pengrajin mengerjakannya di rumah masingmasing, setelah kain tenun songket selesai, kain songket tersebut diberikan kepada induk semang.

Pengerjaan ini dilakukan ketika masing- masing dari induk semang Pandai Sikek langsung memberikan suri dan benang tenunan kepada masing- masing 
pengrajin, dan pengrajin membawanya pulang ke rumah masing- masing pengrajin. Hal ini dilakukan karena masing- masing pengrajin berpendapat bahwa sambil bekerja mereka dapat mengawasi masing- masing keluarganya, dan apabila ia mendapatkan pekerjaan lain berupa buruh tani, ia pun dapat mengerjakannya.

Hal ini berdasarkan dari wawancara yang penulis lakukan dengan Eni ia mengatakan"

"Samanjak sabulan puaso, si wid, anyo masih mangagiah awak banang, tapi tiok sudah kain, disuruahnyo manyimpan kain di rumah ndk usah di agiahan ka anyo, kini di rumah alah ado tigo pasang. (Eni, pengrajin wawancara 29 Juli 2020).

Semenjak Ramadhan, wid sebagai induk semang saya, ia masih memberikan modal dalam pembuatan songket. Akan tetapi jika kain songket tersebut sudah siap, Wid meminta saya untuk menyimpannya di rumah saja, dan di rumah saya sudah menumpuk tiga buah.

b. Induk semang memberikan suri-nya masing- masing kepada pengrajinnya, dan mereka mengerjakannya di rumah induk semang setelah kain tenun songket selesai, kain songket tersebut diberikan kepada induk semang.

Pengerjaan ini dilakukan oleh ketika masing- masing pengrajin dibawa oleh dari induk semang ke rumahnya, awalnya kerjasama ini dalam bentuk transfer of knowledge, dan para pengraji umumnya adalah para gadis- gadis yang belajar bertenun dengan induk semang, mereka diberi keterampilan dalam menenun songket Pandai Sikek dan setelah mereka cakap, mereka diangkat sebagai pengrajin oleh induk semang tersebut Dan para induk semang dapat menekan masing- masing pengrajinnya dalam memberikan batasan waktu kapan kain tenun songket harus diselesaikan, karena mereka tidak kerja sambilan dan masing- masing mereka mendapatkan upah dan apabila induk semang tersebut menemukan cacat pada tenun songket tersebut, mereka memberikan potongan upah disertai arahan agar kain tenun songket selanjutnya dihasilkan secara maksimal

Hal ini berdasarkan pengalaman yang diceritakan oeh Irma, bahwa dalam rentang waktu antara tahun 2010- 2011 ia merupakan pengrajin, dan ia merupakan pengrajin dari Mainar, ia bertenun di rumah induk samangnya

Awak, dek uni, pernah bainduak samang jo tek Mainar, kiro- kiro tahun 2010, awak mangarajokannyo di rumah

\begin{tabular}{l|l} 
Resiprositas dalam Ekonomi Islam... & 133
\end{tabular} 
tek Mainar tu" ( Irma, Pengrajin 16 Agustus 2020)

"Saya pernah memiliki seorang induk semang yang bernama tante Mainar, hal ini sekitar tahun 2010, dan saya mengerjakan tenun songket tersebut di rumahnya"

c. Para pengrajin tenun songket mengambil suri dari induk semang yang nanti diperhitungkan setelah harga kain ditentukan setelah kain tenun songket selesai, kain songket tersebut diberikan kepada induk semang

Mereka umumnya adalah para pengrajin yang memiliki utang kepada para induk semang Pandai Sikek, dan salah satu cara yang dilakukan oleh masing- masing pengrajin membayar utangnya dengan memberikan "anggunan" berupa skill kepada induk semang . Dan apabila tenunan songket itu selesai, maka induk semang langsung memotong upahnya sebanyak utang yang telah diminta, dan apabila ada kelebihan maka dikembalikan kepada pengrajin tersebut. hal ini dijelaskan oleh Len, seorang pengrajin dari Leni " (Len, pengrajin, wawancara November 2019)

"Awak ka maambiak rapor anak wak yang masih di $S D$, kiriman apa nyo patang alah abih untuk bali buku samo kebutuhan akak nyo ka masuak SMA, kain awak alun sudah lai, anyo masuk lo sikola, wa mangecek ka si Leni, anyo amuah meminjamkan pitih dengan syarat gaji wak dipotong, untuk ukuran pemodal si Leni ko rancak ka Rayo diagiahnyo lo bingkisan untuk awak"

Saya mengambil Rapor, anak yang masih duduk di bangku SD, kiriman papanya sudah habis untuk membeli kebutuhan perlengkapan sekolah kakaknya yang mau masuk SMA, songket saya belum selesai, saya pinjam uang dari Leni dengan anggunan kain songket saya yang belum selesai, dengan harapan ketika songket saya selesai, dia memotong gaji saya sebagai bayaran atas utang yang telah diberikan, Sebagai seorang pemodal Leni, termasuk baik kepada anak semangnya, dan juga memberikan bingkisan menjelang lebaran

d. Para pengrajin yang mempunyai peralatan tenun sendiri, dan suri-nya serta bahan bakunya dibeli di tempat masing- masing induk semang atau dibeli di Bukittinggi dan dikerjakan dirumah masingmasing setelah kain telah selesai dijual kepada para saudagar tenun atau ke souvenir di Bukittinggi

Mereka umumnya adalah pengrajin mandiri yang memiliki modal sendiri dalam pengerjaan tenun songket Pandai Sikek, dan mereka umumnya memberikan 
hasil tenunan songket kepada induk semang di Pandai Sikek, atau membawanya ke Bukitinggi atau membawanya ke luar daerah.

Dan berdasarkan keterangan dari pekerja mandiri, mereka tidak bisa menjual hasil tenunannya ke induk semang di Pandai Sikek saat ini, hal ini disebabkan karena pemasaran kain songket mengalami sondai/ kurang laku, dan akibatnya para pekerja mandiri, mereka hanya memiliki dua opsi yaitu meminta suri kepada masing- masing induk semang atau sebagai buruh tani.

Wak bisa manjua hasie tenun ko surang, ndak Paralu modal dari induk semang tenun songket, Patang Ko di bawok si Habil ka Yogyakarta, yo maha panjualannyao, alah tigo kali di bawoknyo ka sinan, si Habil ko bisa manjua saharago $R p \quad 2.300 .000$ 2.500.000, tapi anyo manunggu sampai sabulan sampai tigo bulan, mancari urang nan nio mambali kain ko, Lah di bawoknyo di paragoannyo $k a$ sinan jo kamari, baru basobok pambalinyo. wawancara Darlis, 22 November 2019)

Kita bisa langsung menjual hasil tenunan ini sendiri, tanpa modal dari induk semang kemarin di bawa Habil ke Yogyakarta, ketempat kuliahnya, dan dia sudah tiga kali membawa kesana, dan dia mampu menjualnya seharga $R p$ 2.300.000- 2.500.000, akan tetapi dia harus menunggu sampai tiga bulan untuk mendapatkan penjual tersebut

\section{Pembahasan}

\section{a. Wujud Akad Dalam Bentuk- Bentuk Kerjasama Bisnis Tenun Songket di Nagari Pandai Sikek}

Adapun wujud akad dalam bentuk- bentuk kerjasama bisnis tenun songket antara induk semang dengan pengrajin yang ada di Nagari Pandai Sikek ada beberapa bentuk yakninya, pertama akad ijarah. Eksistensi akad ini terjadi pengrajin yang diberikan suri oleh masingmasing induk semang menyelesaikan tenunannya tersebut, upah ini diberikan kepada masing- masing pengrajin Pemberian upah ini dilakukan secara on-time, akan tetapi berdasarkan wawancara yang penulis lakukan dengan beberapa pengrajin yang ada di Nagari Pandai Sikek tersebut, mereka umumnya mengatakan bahwa pada saat sekarang ini, gaji mereka dibayarkan secara cicilan dan di utang oleh masing- masing induk semang tersebut. Hal ini berdasarkan wawancara dengan sseorang pengrajin tenun songket yang lain, yaitu Un, ia juga berpendapat"

Pitih wak kini ado samo di wid, alun di bayienyo lai. Uni kan tau biasonyo kan awak ma ambiak lado cuma sakali saminggu, kini ko wak bawok duosampai tigo kali saminggu.(Un, \begin{tabular}{l|l} 
Resiprositas dalam Ekonomi Islam... & 135
\end{tabular} 
pengrajin tenun songket Pandai Sikek 30 Agustus 2020)

Saya belum mendapatkan upah dari wid, kakak kan tau biasaya saya hanya menjadi buruh tani dalam ketika kebutuhan mendesak saja, umumnya saya menjadi buruh tani dalam rentang waktu satu kali seminggu, sekarang saya menjadi buruh tani dua sampai tiga kali seminggu.

Akad utang- piutang, eksistensi pelaksanaan akad ini terjadi ketika masing- masing pengrajin yang diberikan suri oleh induk semang yang ada di Nagari Pandai Sikek, ketika pengrajin mengalami kesulitan uang.

Berkenaan dengan utang, ketika pengrajin mengalami kesulitan dana, induk samang akan memberikan pinjaman kepada pekerjanya dengan anggunan kain tenun songket yang sedang dikerjakan dan setelah pengrajin menyelesaikan kain tenun songketnya, induk samang akan memotong gajinya sebagai pembayar utang. Dan utang tersebut dilakukan tanpa adanya bunganya karena induk samang hanya memotong gaji sebanyak utang pengrajin. Hal ini berdasarkan wawancara dengan Len seorang pengrajin dari Leni “

"Awak ka maambiak rapor anak wak yang masih di SD, kiriman apa nyo patang alah abih untuk bali buku samo kebutuhan akak nyo ka masuak SMA, kain awak alun sudah lai, anyo masuk lo sikola, wa mangecek ka si Leni, anyo amuah meminjamkan pitih dengan syarat gaji wak dipotong, untuk ukuran pemodal si Leni ko rancak ka Rayo diagiahnyo lo bingkisan untuk awak " ( Len, pengrajin, wawancara 20 November 2019)

"Saya mengambil Rapor, anak yang masih duduk di bangku SD, kiriman papanya sudah habis untuk membeli kebutuhan perlengkapan sekolah kakaknya yang mau masuk SMA, songket saya belum selesai, saya pinjam uang dari Leni dengan anggunan kain songket saya yang belum selesai, dengan harapan ketika songket saya selesai, dia memotong gaji saya sebagai bayaran atas utang yang telah diberikan, Sebagai seorang pemodal Leni, termasuk baik kepada anak semangnya, dan juga memberikan bingkisan menjelang lebaran.

Akad hibah, akad ini terjadi ketika induk semang, memberikan bantuan cuma- cuma kepada masingmasing pengrajinnya hal ini berupa bantuan dana pendidikan. Hal ini berdasarkan pada keterangan Darlis, ia mengatakan bahwa seluruh biaya pendidikan anaknya yang menempuh pendidikan Strata 1 ditanggung oleh induk samangnya yaitu Ida. Tanggungan biaya pendidikan ini, bersifat pemberian cuma- cuma/ hibah yang diberikan kepada keluarga anak semangnya. Pemberian ini 
berbentuk pemberian sukarela yang diberikan oleh Ida, dan bersifat tanpa ganti rugi dan tanpa mengharapkan apa- apa dari anak semangnya. Hal ini bertujuan membantu meringankan beban anak semangnya, karena ida, sebagai salah satu induk samang di Pandai Sikek, mereka memiliki kelebihan dana, dan ia memprioritaskan pemberian hibah ini kepada salah satu anak semangnya, yakninya Darlis, karena ia menganggap bahwa taraf ekonomi Darlis lebih rendah dari taraf ekonomi anak semangnya yang lain. Hal ini cukup membantu Darlis yang hanya berprofesi sebagai pengrajin saja

\section{b. Kerjasama Bisnis Tenun Songket Dari sisi Hukum Ekonomi Syari'ah}

Menurut Prespektif Hukum Ekonomi Syari'ah bentuk- bentuk kerjasama bisnis tenun songket yang berada di Nagari Pandai Sikek, bukanlah termasuk ke dalam Akad syirkah, hal ini disebabkan karena di dalam akad tersebut tidak memenuhi rukun dan syarat dari sebuah akad syirkah.

Menurut Ahmad Wardi Muslich, adapun persyaratan di dalam syirkah adalah sebagai berikut:

a. Tasaruf yang menjadi objek akad syirkah harus bisa diwakilkan

b. Pembagian keuntungan harus jelas

c. Keuntungan harus dimiliki bersama (Muslich, Fikih

Muamalah, 2010, p. 353)

Eksistensi dari akad syirkah adalah penggabungan dalam modal, pekerjaan, keuntungan berserta kerugian sesuai dengan kesepakatan yang telah disepakati oleh kedua belah pihak pihak (Harun, 2000, p. 166)

Dalam bentuk- bentuk kerjasama bisnis tenun songket di Nagari Pandai Sikek, berkenaan dengan keuntungan dan kerugian semuanya dimiliki oleh induk samang saja, karena penjualan berserta keuntungan bukanlah hak dari pengrajin, mereka tidak mengetahui berapa keuntungan yang dimiliki para induk samang dalam memperdagangkan hasil tenunan mereka. Sedangkan pekerja hanya berhak atas upah yang telah ditetapkan padanya

Dan menurut penulis, praktek kerjasama tenun songket di Pandai Sikek termasuk kedalam transaksi akad ijarah. Akad ijarah menurut alSyarbani al- Khatib adalah

عقد على منفعة مقصودة معلومة مباحة قابلة

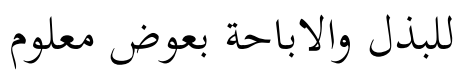

"Transaksi terhadap suatu manfaat yang tertuju, tertentu, bersifat mubah dan boleh dimanfaatkan dengan imbalan tertentu" (Khatib, Mughni al Muhtaj juz 2, 1978, p. 233)

\begin{tabular}{l|l} 
Resiprositas dalam Ekonomi Islam... & 137
\end{tabular} 
Dalam praktek ujrah yang dilakukan oleh induk samang dangan pengrajin tenun songket di Nagari Pandai Sikek bersifat mengikat antara induk samang dengan pengrajinnya. Hal ini dibuktikan dengan terikatnya hubungan kerja antara kedua belah pihak.Pertama, dari sisi Induk samang, mereka tidak memecat pengrajinnya ketika pemasaran kain songket mengalami sondai/ kurang laku, mereka hanya menangguhkan pemberian suri dan upah kepada masing- masing pengrajinnya, dan apabila pemasaran kain songket laku kembali mereka kembali memperkerjakan masing- masing pengrajinnya yang mengalami masa " cuti" untuk kembali bekerja. Para induk samang, mereka umumnya berpendapat bahwa penyebab pemasaran kain tenun songket mengalami sondai/ kurang laku disebabkan oleh faktor alam bukanlah disebabkan dengan adanya campur tangan manusia/ praktek monopoli.

Menurut mereka ada dua faktor alam yang menyebabkan pemasaran kain songket mengalami sondai yaitu pertama tingginya tingkat kebutuhan masing- masing individu pada bulan- bulan tertentu dalam kalender Arab yang menyebabkan mereka mengalihkan pembelian kain tenun songket pada bulan- bulan lainnya seperti kebutuhan lebaran serta adanya mitos yang dipercaya di Nagari Pandai Sikek bahwa pada bulan Muharram pembelian kain songket mengalami muram/ kurang diminati pembeli.(wawancara dengan Un, pengrajin tenun songket Pandai Sikek, via telpon 30 Agustus 2020), kedua saat sekarang ini dengan adanya faktor pandemi yang sedang dihadapi oleh masyarakat Indonesia.

Kedua, dari sisi pengrajin, yaitu hanya produksi yang dihasilkan oleh masing- masing pekerjanya yang berhak dipasarkan di galeri- galeri induk samang, masing- masing hal ini merupakan bentuk perlindungan yang diberikan oleh induk samangnya kepada para pengrajinnya, agar pengrajinnya memiliki taraf hidup yang lebih baik dari pada pengrajin mandiri yang berada di Nagari Pandai Sikek.

Disamping bersifat mengikat antara masing- masing pelaku akad, akad upah- mengupah tenun songket yang ada di Nagari Pandai Sikek mengandung komiten yang kuat antara kedua belah pihak. Komitmen ini disebut juga dengan keterlekatan (embedded) (Damsar, 2009, p. 139). Damsar, ia berpendapat bahwa keterlekatan adalah suatu tindakan ekonomi yang disituasikan secara sosial dan melekat dalam jaringan personal yang sedang berlangsung diantara para aktor./ pelaku ekonomi (Damsar, 2009, p. 139). 
Secara sederhana keterlekatan (embedded) difahami terwujudnya hubungan yang melekat serta antara dua pelaku- pelaku akad yang menyebabkan munculnya hubungan interaksi sosial antara keduanya, jadi hubungan antara dua pelaku akad tersebut tidak hanya berorientasi pada hubungan profit saja, tetapi terwujudnya sebuah relasi/ hubungan sosial antara dua belah pihak.

Keterlekatan dalam praktek upah- upah hal ini dapat terjadi ketika hubungan antara induk samang dengan pengrajinnya terjalin dengan sangat baik. Hal ini menurut penulis, ketika induk samang hanya menerima hasil tenunan dari pengrajinnya masingmasing dan induk samang memberikan hadiah, bingkisan serta hibah memberikan hibah kepada anak pengrajinnya, hal membuktikan bahwa praktek ba-induk samang yang ada di Minangkabau, khususnya dalam praktek upah- mengupah tenun songket di Nagari Pandai Sikek hubungan kerja antara antara kedua pelaku akad yakninya induk samang dengan pekerjanya/ pengrajinnya merupakan hubungan mitra bisnis, yang mana hubungan antara dua pelaku akad tidak hanya berorientasi kepada profit saja, akan tetapi juga berorientasi kepada hubungan sosial yang terikat dengan kepercayaan/ trust. (Damsar, 2009, p. 157).
Berdasarkan hal di atas, difahami bahwa hubungan kerja sama yang berbentuk hubungan sosial yang dilandasi dengan kepercayaan seperti halnya dengan praktek upah mengupah yang ada di Nagari Pandai Sikek, mengambarkan bahwa terbentuknya sebuah jaringan bisnis tenun songket yang ada di Nagari Pandai Sikek, (Damsar, 2009, p. 157) hubungan ini terbentuk ketika induk samang mempercayakan suri-nya untuk digarap dikerjakan oleh pengrajinnya masing- masing.

Disamping, terwujudnya sebuah interaksi sosial diantara pelaku akad, embedded/ keterlekatan/ komitmen dalam ekonomi juga berpengaruh institusi- institusi yang ada di masyarakat, seperti seperti institusi sosial, politik, dan agama (Damsar, 2009, p. 142), hal ini dapat difahami bahwa praktek- praktek ekonomi yang ada di masyarakat, ditujukan tidak hanya mencari keuntungan keuntungan saja, akan tetapi harus mempertimbangkan nilai- nilai dan norma yang berlaku bagi pelaku usaha tersebut. Khususnya dalam praktek- praktek upah- mengupah yang ada di Nagari Pandai Sikek, semestinya mempertimbangkan nilainilai ekonomi Islam, sebagai norma yang harus ditaati oleh pelaku pelaku ekonomi tersebut. Di dalam Islam memandang bahwa distribusi kekayaan merupakan salah satu \begin{tabular}{l|l} 
Resiprositas dalam Ekonomi Islam... & 139
\end{tabular} 
bentuk mewujudkan kesejahteraan masyarakat Muslim. (Agustini, 2017, p. 159)Kebijakan ini ditujukan untuk mewujudkan pemerataan publik, agar kekayaan tidak hanya dinikmati oleh segelitir saja, tetapi juga dapat dapat memberikan konstribusi kesejahteraan secara menyeluruh.

Islam memandang bahwa kekayaan yang dimiliki manusia bersifat majasi (Wahbah al- Zuhayliy, 2011, p. 28), maksudnya kepemilikan harta kita hanyalah amanat yang telah diberikan oleh Allah, dan maka oleh sebab itu konsekuensinya bahwa pengeloaan harta di dalam Islam harus sesuai dengan kehendak Allah sebagai pemilik harta ini, dan posisi manusia sebagai pengelola samasama berhak untuk mendapatkan kekayaan yang telah diberikan oleh Allah tersebut, dan agar terwujudnya pemerataan kakayaan di dalam Islam, Islam mewajibkan distribusi kekayaan bagi umatnya yang memiliki kelebihan harta.

Menurut penulis, salah satu bentuk penerapan distribusi kekayaan dalam praktek- praktek upah mengupah dalam usaha tenun songket di Pandai Sikek adalah pemberian hibah, zakat, hadiah, serta bingkisan dari pihak induk samang yang dianggap memiliki kelebihan dana, guna menopang ekonomi masing- masing pekerjanya

\section{PENUTUP}

Bentuk- bentuk kerjasama yang dilakukan antara induk semang dengan pengrajin yang ada di Nagari Pandai Sikek ada dalam bentuk empat macam yaitu a) induk semang memberikan manfaat dari suri dan benang-benang kepada masingmasing pengrajinnya, kemudian pengrajin mengerjakannya di rumah masing- masing, dan setelah tenun songket selesai, dia akan memberikan kepada induk semang-nya b) induk semang memberikan manfaat dari suri dan benang-benang kepada masing- masing pengrajinnya, kemudian pengrajin mengerjakannya di rumah induk semang, dan setelah tenun songket selesai, dia akan memberikan kepada induk semang-nya c) Para pengrajin meminta benangbenangnya dari induk semang, diperhitungkan setelah tenun songket selesai dan hasilnya diberikan kepada induk samang. d) para pengrajin yang memiliki peralatan tenun songket dan benang- benangnya dibeli dari induk semang yang ada di Nagari Pandai Sikek atau yang berada di Bukittinggi, kemudian dikerjakan di rumah masing- masing pengrajin, dan setelah tenun songket selesai, mereka menjualnya kepada induk samang yang berada di Nagari Pandai Sikek atau toko souvenir yang ada di Bukittinggi. 
Dalam praktek ekonomi Islam, praktek kerjasama bisnis tenun songket yang ada di Nagari Pandai Sikek, termasuk ke dalam praktek ijarah yang bersifat Resipositas, yaitu akad ijarah yang terkandung di dalamnya akad tolong- monolong antar kedua pihak yang berakad, dan dapat dikatakan bahwa akad ijarah tersebut bersifat Resipositas hal ini dapat dinyatakan bahwa praktek upah- mengupah ini tidak hanya dalam bentuk hubungan materil saja, akad tetapi juga mengandung akadakad sosial.

\section{KEPUSTAKAAN ACUAN}

Agustini, A. W. (2017). Distribusi kekayaan dalam Islam. Jurnal Tazkiya: jurnal ke Islaman, kemasyarakatan dan Kebudayaan, Vol 18. N0 2 (Juli-Des),

Azwar Iskandar \& Khaerul Aqbar. (2019). kedudukan Ilmu Ekonomi Islam Diantara Ilmu Ekonomi Dan Fikih Muamalah :Analisis problematika epistemologis. Nukhbatul 'Ulum : Jurnal Bidang Kajian Islam, Vol. 5, No.

BPS Tanah Datar. (2018). Kecamatan Sepuluh Koto dalam Angka. Batusangkar:

Chrityawati, Eni (2009) Kontinuitas Pola pewarisan Seni Menenun
Songket di Nagari Pandai Sikek, X Koto, Tanah Datar, Desbudpar, Balai Pelestarian Sejarah dan Nilai Tradisional Padang

Creswell, J. W. (2009). Research Design: Qualitative, Quantitative and Mixed Methods Approaches. Los Angles: Sage Publishing.

Damsar. (2009). Sosiologi Ekonomi. Jakarta: Kencana.

Evita Edila Putri, Zaini Abdul Malik Dkk. (2017-2018). Analisis Fikih MuamalahTerhadap Praktek Driver Gojek. Prosiding Hukum Ekonomi Syari'ah. Bandung: Universitas Islam Bandung.

Muhammad. (2004). Etika Bisnis Islam. Yogyakarta: Unit Penerbit dan Percetakan Akademi Manajemen Perusahaan YKPN.

Nanang. (2015). Metode Penelitian Sosial. Jakarta: PT Raja Grafindo Persada.

Nawawi, I. (2012). Fikih Muamalah Klasik dan Kontemporer. Bogor: Ghalia Indonesia.

Haroen, N. (2000). Fikih Muamalah. Jakarta: Gaya Media Pratama.

Khatib, A. S. ( 1978). Mughni al Muhtaj juz 2. Beirut: Dar al- Fikr

Muslich, A. W. (2010). Fiqh Muamalah. Jakarta: Amzah. 
Nagari Pandai Sikek. (2019). Arsip Nagari Pandai Sikek.

Nur, E. R. (2015). Riba dan Gharar Suatu Tinjuan Hukum Dan Etika Dalam Transaksi Bisnis Modern. Jurnal Al' Adalah, Vol VII, No. 3 Juni.

Riri Purnama Sari\& Zainuddin. (2019). Kerjasama Driver Dengan Perusahaan Aplikasi GOJEK ONLINE Presoektif Fikih Muamalah. Jurnal Hukum Islam, Vol XIX 1 JUNI.

Sugiyono. (2015). Metode Penelitian Manajemen. Alfabeta: Bandung.

Suliastani, S. L. (2018). Eksistensi Filsafat Hukum Islam Dalam Pengembangan Ekonomi Islam di Indonesia. Jurnal Amwaluna, Vol 12 No. 1 Januari.

Syahril, S. (2019). Metode Studi Islam Komprehesif dan Implikasinya terhadap Corak Pemikiran Aliran- aliran dalam Islam. Analisis: Jurnal Studi Keislaman, Vol. 19 No. 2 Juni.

Saydam, G. (2004). Kamus Lengkap Bahasa Minangkabau. Padang: Pusat Pengkajian Islam dan Minangkabau Sumatera Barat

Turmudi, M. (2017). Mplementasi Akad Percampuran Dalam Hukum Ekonomi Syari'Ah. Jurnal Al-'Adl Vol. 10 No. 2, Juli.

Zuhayli, W. a. (2011). Figh al- Islamiy wa Adillatahu, juz 4. Beirut: Dar al- Fikri

Wawancara dengan Darlis

Wawancara dengan Irma

Wawancara dengan Len

Wawancara dengan Un, pengrajin tenun songket. 